\title{
The analysis of linguistic variation in Translation Studies. A proposal for classifying translational phenomena between source text and target text
}

\author{
SANTIAgo Del Rey QuesadA \\ sdelrey@us.es \\ Universidad de Sevilla
}

Fecha de recepción: 13 de diciembre de 2019

Fecha de aceptación: 26 de febrero de 2020

\begin{abstract}
This paper addresses the study of variation in translated texts from a theoretical-methodological perspective. The first section focuses on the determining factors affecting diasystematic variation in the variational space of languages, a concept emerging from the field of German variational linguistics, where I refer to the domains of communicative immediacy and communicative distance, two concepts essential for understanding the classification proposed in the following pages. The second section is devoted to the type that I have called contact-based variation, defining language variants attributable to the situation of contact in which all translations are produced. The third section briefly covers what I have termed gradational variation, i.e. the existence of forms that are intensified or attenuated with respect to others. The fourth section describes how the three types of variation interrelate in target texts and establishes a typology of phenomena aimed at explaining variants in translated texts, revolving around the concept of interference. Lastly, the viability of this proposal for analysing variants in the field of descriptive, historical, and applied linguistics is discussed.
\end{abstract}

Resumen: En este artículo me intereso por el estudio de la variación en los textos traducidos desde una perspectiva teórico-metodológica. En un primer epígrafe, discuto los condicionantes que afectan a la variación diasistemática en el espacio variacional de las lenguas, concepto surgido en el ámbito de la lingüística de variedades alemana, y me refiero a los conceptos de 'ámbito de la inmediatez' y 'ámbito de la distancia' comunicativas, fundamentales para comprender la clasificación que propongo a lo largo de las siguientes páginas. En el segundo epígrafe, me centro en la variación basada en el contacto, es decir, la que explica las variantes de lengua atribuibles a la situación de

\footnotetext{
* This paper has been written within the context of the project "Tradicionalidad discursiva e idiomática, sintaxis del discurso, traducción y cambio lingüístico en la historia del español moderno: prosa (pre-)periodística/ensayística y literaria (PGC2018-097823-B-I00)" founded by the Ministry of Science, Innovation, and Universities of the Spanish Government.
} 
contacto en que se desenvuelve toda traducción. En el tercer apartado, me refiero brevemente a la variación que denomino gradativa, que explica la existencia de formas intensificadas o atenuadas respecto de otras. En la cuarta sección, se verá cómo se interrelacionan los tres tipos de variación en los textos meta y se ofrece una tipología de fenómenos tendentes a explicar las variantes en textos traducidos, con foco en el concepto de interferencia. Por último, se discute la rentabilidad de esta propuesta para el análisis de variantes en el ámbito de la lingüística descriptiva, incluyendo la lingüística histórica, y de la lingüística aplicada.

Keywords: Diasystematic variation, Contact-based variation, Linguistic interference, Translation

Palabras clave: Variación diasistemática, variación basada en el contacto, interferencia lingüística, traducción

\section{LINGUISTIC VARIATION (1): THE DIASYSTEM}

That language is variation has been a theme closely related to contemporary linguistics since the advent of the sociolinguistic approaches proposed by Bernstein and Labov in the 1960s. From a more demanding theoretical perspective, it should be noted that language is a set of varieties, that only speech is variation, for the heterogeneous whole making up variation can only be identified with the phenomenal reality from which the linguist departs to construct objects of study - to wit, varieties-in order to theorize (to do science) on the nature of (historical) languages. ${ }^{1}$ Variation takes many shapes in a language. Of course, one of the most blatant indications of variation is linguistic change considered from a diachronic perspective: languages change over time. But the historical functioning of languages is not only apparent in diachrony, for in synchrony these also change in accordance with certain geographical, sociocultural, and situational parameters.

Taking into consideration these parameters, and departing from the idea of the architecture de langue put forward by Flydal (1951), Coseriu ([1957] 1988, 1980) designed the theoretical structure of the diasystem, ${ }^{2}$ distinguishing differentiated functional languages identified with diatopic, diastratic, and diaphasic varieties. Even though it is true that, beside theorizing in this respect, specific studies on variation, specifically those preformed in the field of sociolinguistics since its Labovian beginnings, have put the accent

1 On the difference between the subject of study and doing science on such a subject, cf. López Serena (2019: 13-17]).

2 The initial formulation of this concept is Weinreich's ([1953] 1967).

Hikma 19 (1) (2020), $209-237$ 
on spoken language, in the past decades research on language variation has also been fruitful in those studies employing written texts as a corpus. This has been particularly the case with the German Romanists who have given this new approach to variation analysis a warmer welcome, above all on the basis of the chain of varieties model ${ }^{3}$ proposed by Peter Koch and Wulf Oesterreicher ([1990] 2007), reworking, in point of fact, the ideas of Coseriu, a model in which the continuum between communicative immediacy and communicative distance forms the backbone of the variational space of historical languages. The distinction that these authors draw between conceptual orality and conceptual scripturality has had a meliorative impact on the consideration of (medially) written texts as a legitimate source for studying language variation in diverse sychronies of international European languages.

The analysis of variation poses a real challenge in translation studies. In translation practice per se, the consideration of variational aspects is a complex task, since, as Brumme and Espunya (2011: 11) note, "it seems probable that the historical-idiomatic ${ }^{4}$ characteristics belonging to only one language do not have a direct correlation in the target text", whereby the correspondences between the levels of variation described in this section are not always easy to pinpoint. But, moreover, the study of variation in translated texts should be addressed according to well-defined theoretical premises that underscore the difference between a marked variant and a non-marked one in a given historical language.

I have recently pondered on the problem of marking in the chain of varieties described by Koch and Oesterreicher ([1990] 2007: 37-40), in whose context I would also like to consider diasystematic phenomena in translated texts. The chain of varieties' aim is to describe how the variational space of languages is shaped, this being understood as the set of diatopically, diastratically, diaphasically, and conceptually ${ }^{5}$ determined varieties that

3 Cf. López Serena (2007); Del Rey (2020).

4 By "historical-idiomatic" the authoresses are referring to phenomena that, according to the chain of varieties model, pertain to the diasystematic and conceptual levels inherent to each particular historical language, that is, not to the universal phenomena determined by the variation between communicative immediacy and communicative distance (cf. Koch and Oesterreicher [1990] 2007, 37-38).

5 According to Koch and Oesterreicher ([1990] 2007, 38]), the conceptual dimension is "la expresión directa [en una lengua histórica determinada] del continuo universal entre inmediatez y distancia comunicativa" [the direct expression [in a specific historical language] of the universal continuum between communicative immediacy and communicative distance]. For these authors, it is the most relevant dimension of the chain of varieties, insofar as it "comprende todos los hechos lingüísticos histórico-idiomáticos que resultan de las condiciones comunicativas y estrategias de verbalización" (ibid.) [it comprises all the historical-idiomatic linguistic events resulting from the communicative conditions and strategies of verbalization], which makes it 
explain their historical functioning. This space is hierarchical, for which reason the authors speak of a chain: at the diasystematic level, diatopic features can function as diastratic ones and the latter as diaphasic ones, though not vice versa. $^{6}$

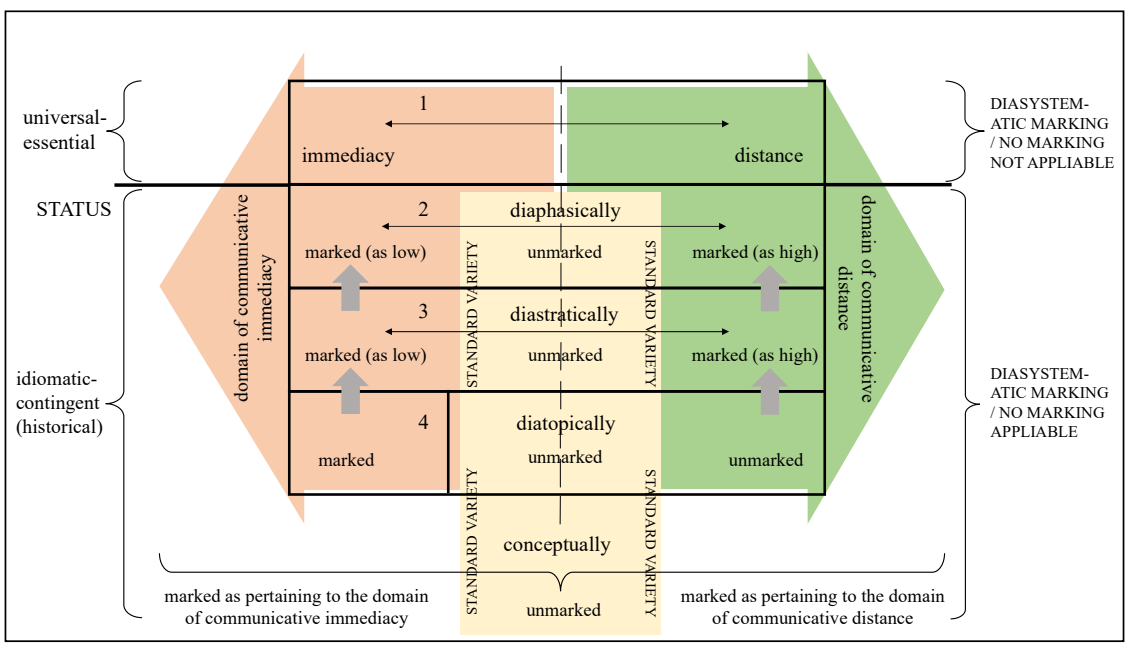

Figure 1. New proposal for the chain of varieties

Source: Del Rey (2020)

According to the new chain of varieties proposed in Figure 1, which modifies substantially the original model devised by Koch and Oesterreicher, I have insisted on the need to consider as being marked in a language not only those phenomena that fit into the left side of the schema, viz. phenomena which are diatopically marked ${ }^{7}$ and/or diastratically and/or diaphasically marked as low, but also those appearing on the right side, namely, phenomena which are diastratically and/or diaphasically marked as high. It is precisely these phenomena that, from the perspective of Koch and

possible to distinguish the communicative constellations inherent to immediacy and distance, alike.

6 This idea goes back to Coseriu $(1980,112)$. The chain of varieties model allows us to explain why educated speakers are able to move in the variational space of their mother tongue with greater ease than those with little or no education.

7 One of the modifications that I propose with respect to the model developed by Koch and Oesterreicher ([1990] 2007, 36-40) is that the diatopical level is not conceived, as the German authors do, as a continuum between diatopically strong and diatopically weak variants, but as a dichotomy between diatopically marked and diatopically unmarked phenomena (for the rationale behind this change, cf. Del Rey 2020).

Hikma 19 (1) (2020), $209-237$ 
Oesterreicher and many other researchers, ${ }^{8}$ are identified with standard language, this being understood as the benchmark variety (due to its prestige) of a historical language. To my mind, however, the chain of varieties model can be exploited to shift the standard variety towards the centre of the model, thus allowing it to be identified with diatopically, diastratically, and diaphasically unmarked phenomena in a particular historical language. As unmarked phenomena, linguistic variants pertaining to the standard variety could be used in both communicative immediacy-which, in my reformulation of the model, corresponds to diatopically marked phenomena and/or to those diastratically and/or diaphasically marked as low-and communicative distance-which, as before, and according to my proposal, includes those phenomena that are diatopically unmarked and/or diastratically and/or diaphasically marked as high. ${ }^{9}$

In order to understand the classification of the types of variational phenomena identified in $\S 3$, it was first essential, as I have pretended in this section, to distinguish between marked and unmarked —or standard—variants in the diasystem of a language.

\section{LINGUISTIC VARIATION (2): CONTACT AND INTERFERENCE}

The phonetic, morphosyntactic, and lexical-semantic variants in a specific historical language are due to the diatopical, diastratic, diaphasici.e. diasystematic-conceptual and diachronic constraints to which I have referred in the previous section. These variants would exist even if a language were isolated from the rest, provided that it were spoken by a sufficiently large and heterogeneous linguistic community. Nonetheless, there are other variants that can be explained as a result of the contact between languages, which produces anomalous, unusual, or new forms and structures in them or leads to the preferential use of a form or structure over other available ones as a result of such contact. This type, which I will call 'contact-based variation' is also essential for explaining linguistic change. Contact-based variation does

8 For a more detailed explanation in this respect, cf. Del Rey (2020).

9 Another substantial modification resulting from my proposal is to understand what Koch and Oesterreicher ([1990] 2007, 37-40) have termed "conceptual variation", the central level of the chain according to these authors, as being diasystematic. In my opinion (cf. also Selig 2011), as a type of variety integrating the rest-diatopical, diastratic, and diaphasic-it seems inappropriate to claim that a particular unit cannot be conceptually marked in communicative immediacy or distance. At an idiomatic-contingent level, this implies, in turn, that in my proposal the conceptual dimension does not represent a level overlapping the diaphasic one in the chain (as indeed occurs in the original model), but a level integrating the other varieties, also on a continuum, as indicated by the broad arrows to the left and right of the model in Figure 1.

Hikma 19 (1) (2020), 209 -237 
not oppose the diasystematic kind, but interacts with it. ${ }^{10}$ As a result of contact, therefore, a variant diaphasically marked as low in Language A can produce, for instance, an anomalous (or, in principle, asystematic) structure in Language $B$, which, in any case, will continue to be a diaphasically marked variant in the latter.

Although language contact studies have traditionally focused on oral interactions, this work is based on the conviction that in written texts translation can be regarded as a specific form of language contact, as scholars such as House (2009) or Malamatidou (2016), amongst others, ${ }^{11}$ have put forward. From the perspective proposed here, the label "language contact", which is being increasingly more postulated as a specific research sub-discipline (cf. Hickey ed. 2013), would serve as a hyperonym of "translation", as could related sub-disciplines like comparative linguistics, contrastive grammar, and any other whose interest lies in the linguistic analysis of the processes and products originating from the mutual or oneway influence of one language on another. Some authors, including Haßler (2001: 154-158), have stressed certain differences between translation and the language contact phenomenon. Among them, this authoress highlights that in translation there is an awareness of contact production, which is not the case in prototypical language contact phenomena. In this connection, translators can reflect on what they produce and thus avoid possible interferences.

The concept of 'interference' is central to language contact and especially to translation studies (cf. Del Rey 2018a). This normally refers to the incorporation of abnormal or even asystematic units or constructions in the target text (TT), deriving from the influence of the source text (ST). It is this unflattering vision of the concept that used to predominate in research ${ }^{12}$. Newmark (1991: 78) proposes a less prescriptive definition for "interference", precisely using the term translationese to indicate the types of interference that, generated in the field of translation by an excessive literality on the part of the interpreter, lead to the distortion of meanings in the ST or to a contravention of the original use for no apparent reason.

\footnotetext{
${ }^{10}$ Some interesting remarks on the contact between language varieties can be found in Mattheier (1996).

${ }^{11}$ Cf. also Haßler (2001); Albrecht (2017); Del Rey, Del Barrio, and González (2018).

${ }^{12}$ Scholars studying the relationships between translation and cognition often rely on this negative conception of interference. The interest of "avoid[ing] interference" (Martín de León 2017, 122), in connection with the warning about the "danger" (Göpferig 2017, 409, 416) that it poses, bears out this general view of the phenomenon. $\mathrm{Cf}$. a historiographical discussion of the problem in Kupsch-Losereit 2004).
} 
Following the approach employed by Weinreich ([1953] 1967) to the study of interference and relying on the ideas and concepts developed by Coseriu (1977), Kabatek (1997, [1996] 2000) postulates a typology of interference ${ }^{13}$ conceived as the consequence of language contact which has nothing to do with the unflattering vision of the concept held by many translatologists. According to this author, in contact situations it would be necessary to differentiate between two types of interference principles: positive interference and negative interference. The former gives rise to types of interference with directly verifiable results in the discourses produced. Namely, phenomena relating to positive interference produce elements positively present in texts. According to the typology of variants in translated texts that I will present in §4, these elements would involve marked variants, regardless of whether this marking is understood as a result of diasystematic, contact-based, or gradational variation (cf. §3). Negative interference does not produce elements positively present in a discourse, to wit, according to my terminology applied to the field of translatology, it refers to the presence of unmarked elements in TTs. This signifies that, with respect to contact-based variation, the interference of the ST in the TT does not produce abnormal or asystematic results as a consequence of contact and/or, with regard to diasystematic variation, the resulting variants in the TT represent unmarked elements from a diasystematic perspective, that is, they represent standard units. With regard to gradational variation, unmarked elements correspond to neutral linguistic values in TTs (cf. §3). The negative character of the second type of interference has by no means derogatory connotations ${ }^{14}$, but has to do with the absence of certain variants in the TT as a consequence of interference, in such a way that the results in this TT are neither discernible for the receiver of the message nor for the analyst, unless the ST used by the translator is available.

While positive interference satisfies the defining characteristics of the prototypical processes of interference, since it is apparent in the results positively present in texts (as already noted), the linguistic manifestations of negative interference, insofar as they correspond to the results not positively present in texts, tend to be discarded by researchers as products of interference. What I am trying to say is that it is not uncommon for scholars to hold that negative interference is not interference at all (cf. Del Rey 2018a: 54 n. 9).

\footnotetext{
${ }^{13}$ I have attempted to apply this typology to the analysis of texts translated in different periods, with essential adaptations (cf. Del Rey 2016b, 2017).

14 Toury's $(1995,288)$ distinction between positive and negative transfer is based on the degree of interference acceptability in the TL. Thus, his terminology maintains the most general connotations of these adjectives, in contrast to Coseriu's and Kabatek's proposal.
} 
However, the theoretical premise that I am employing to justify the fact that it is also possible to speak of interference in these cases, at least in the translatological context that interests us here ${ }^{15}$, is that the ST always conditions (that is, interferes with) the linguistic configuration of the TT when what is involved are language variants. ${ }^{16}$ This conditioning can involve the conscious (evident in the case of difference-cf. §4-i.e. in the use of a unit differing from that of the ST, despite the fact that the translator is aware that the target language's system possesses an identical or more similar variant to the unit of the ST) or unconscious (in the case of identity, when the translator does not review the paradigmatic possibilities of translation that the target language's system offers for a specific structure $)^{17}$ choice on the part of the translator.

Of course, it is hard and, in the case of ancient translations, indeed impossible, to know when this conditioning is conscious or unconscious. Nowadays, professional translators have a perfect command of the language from which and, especially, into which they translate, and in this respect they are probably aware of all of the convergence and divergence phenomena (cf. $\S 4$, Fig. 3) to be found in their translations.

\footnotetext{
${ }^{15}$ In this sense, I fully agree with Toury $(1995,312)$, when he states, "as, psycholinguistically speaking, there seems to be only one procedure which yields both ['positive' and 'negative' transfer], interference as such will always be present. It may just be more or less easy to discern." ${ }^{16}$ In principle, an invariant in the target language (TL) cannot be explained as a product of an interference process. In other words, to be able to talk about interference it is necessary to determine whether or not the phenomenon analysed in the TT corresponds to a paradigmatic possibility among at least two in order to express the same or a similar function or meaningrather than entering into the argument about the possibility of translating exactly the same meanings into other languages, I refer readers to Toury (1995) and his idea that translations are facts that belong to target culture and which can even construct their own (sub-)systems. For instance, in the syntagm "la maison" as the translation for "the house", both the article (la) and the noun (maison) are variants, as shown by the fact that they can be substituted by other elements such as cette, celle, une, etc., and habitation, foyer, logis, etc., respectively. Nevertheless, the syntactic form in which the function of determination is presented is an invariant, since the French system only allows the determinant to precede the determined, that is, the only possibility of expressing the function of determination is la maison, and not *maison la, for example. So, the fact that, in this syntagm, the determinant precedes the determined cannot be justified by the fact that it also appears in that order in the syntagm of the ST, but because it is the only systematic possibility in the TL.

${ }^{17}$ As will be seen further on ( $\left.\$ 4\right)$, in the case of positive interference its effect can also be conscious or unconscious. About conscious vs. unconscious tasks in translation from a cognitive perspective, cf. Jääskeläinen and Tirkkonen-Condit (1991).
}

Hikma 19 (1) (2020), $209-237$ 


\section{LINGUISTIC VARIATION (3): GRADATION}

There is a third type of variation that is of special interest in the field of translatology: that referring to the gradation-for which reason I have chosen to call it gradational variation-of units in a language pursuant to the processes of intensification and attenuation to which different linguistic units can be subjected. Intensification and attenuation can be semantic and/or morphosyntactic. At both levels of analysis, it should be assumed, at least in translational contexts, that there exist unmarked or neutral linguistic units on the semantic or discursive-syntactic scale. Thus, at a semantic level, the term "giant" is a semantic intensification of "big". At a morphosyntactic level, "bigger" or "biggest" are similarly an intensification of "big". At a discursivesyntactic level, it is also possible to observe processes of intensification consisting in focusing on elements: for instance, the textual variant "John did this job" is neutral with respect to the intensified "It was John who did this job". Regarding attenuation, at a semantic level the euphemism is a clear exponent of this strategy. At a syntactic level, "not good" is an attenuated structure in relation to "bad".

All things considered, of the three types of variation analysed here gradational marking is the most difficult to perceive positively in texts when there is no adequate context of comparison, such as that which allows the ST and the TT to be contrasted (cf. §4). Of all the types of variation addressed in this paper, the contact-based type yields the largest number of results in texts in relation to positive interference and can even be perceived in the absence of the ST. Diasystematic marking is harder to verify without comparing the ST with the TT, but, at any rate, it can usually be observed in a given text when a variant is marked in the context of communicative immediacy or communicative distance. Be that as it may, gradational marking can go unnoticed if two variants are not contrasted. In English, for example, the statement "he has a lot of money" does not necessarily have to be considered as being (hyper-)gradated, unless it is compared with "he has money". On the other hand, while in the case of adjectives positive gradation is identified with the unmarked gradational variant, the types of gradational relationships are more often than not hard to determine, for it is not always easy to establish a variant that is gradationally neutral versus another or others. Yet, at a discursive-syntactic level, the use of marking elements, such as those that Bolinger (1972: 17) calls "boosters"-for intensification, as in "he is a perfect idiot"-and "diminishers" and "minimizers"-for attenuation, as in "he's a bit of an idiot"-make it possible to locate gradationally marked variants with 
respect to statements lacking such elements, which may be considered gradationally neutral. ${ }^{18}$

After reviewing the different types of variation that can be found in translated texts-i.e. diasystematic $(\S 1)$ and those which I have termed "contract-based" (§2) and "gradational" (summarized in this section)-in the following section I will propose a classification of translation phenomena that, to my mind, allows us to offer a full explanation for the causes-and consequences - of variation in the field of translation studies.

\section{A COMPREHENSIVE PROPOSAL FOR THE STUDY OF VARIATION IN TRANSLATED TEXTS}

In this section, my main aim is to propose a number of descriptive categories for the processes of interference in the analysis of translated texts. The purpose is none other than to gain a better understanding of the translational aspects underlying their production. ${ }^{19}$ Although it should be stressed that this classification does not intend to be definitive, but will have to be tested in specific analyses according to the idiomatic and discursive ${ }^{20}$

\footnotetext{
${ }^{18}$ Due to space limits, it is impossible to elaborate any further on this type of variation. The concept of 'gradation', which has been a key problem in semantics since Lyons (1977), would require a comprehensive review of related concepts such as 'size', 'quantity', 'amplification', 'superlativeness', etc. For a summary of these conceptual issues, cf. Bolinger (1972) and Albelda (2005).

${ }^{19}$ In this connection, I fully agree with López Serena (2019): "En términos epistemológicos, lo que hacemos cuando proponemos determinados niveles y unidades de análisis para el estudio de los fenómenos discursivos cuyo comportamiento nos interesa describir no es sino establecer clases generales o categorías fenoménicas a partir de la diversidad de hechos que nos muestra la realidad del discurso, algo inherente a toda actividad científica. [...] No hay ciencia sin categorías o unidades de análisis, esto es, sin la estipulación de clases de individuos cuyas propiedades y comportamiento sean susceptibles de describirse de acuerdo con unas mismas regularidades. [...] Al científico no le interesan las clasificaciones conceptuales por sí mismas, sino la obtención de leyes [...], o en el caso de las ciencias humanas, la detección de regularidades interesantes a partir de las categorías de análisis con que se trabaje" [In epistemological terms, when we propose specific levels and units of analysis for studying discourse phenomena whose behaviour we are interested in describing, this is tantamount to establishing general classes or phenomenal categories on the basis of the diversity of the facts that the reality of the discourse shows us, something inherent to all scientific activity. [...] There is no science without categories or units of analysis, namely, without stipulating the classes of individuals whose attributes and behaviours are susceptible to being described according to the same regularities. [...] Scientists have no interest in conceptual classifications per se, but in obtaining laws [...], or in the case of human sciences, in detecting interesting regularities on the basis of the categories of analysis employed].

${ }^{20}$ By differentiating between idiomatic and discursive characteristics, I assume the dual specificity of the historical level of language to which Koch (1997) refers, who at this level distinguishes between language rules per se (those referring to phonetics and phonology, grammar, vocabulary, etc. of each particular language) and discursive ones (determined by the discourse
}

Hikma 19 (1) (2020), 209 -237 
idiosyncrasies of each language. For even though the phenomena that I will describe below do not aspire to being universal, they do indeed possess a supra-idiomatic character, i.e. they are understood as susceptible to being applied, in principle, to the relationship between the ST and the TT in different languages with their own literary tradition. ${ }^{21}$

So, in Graph 2, I have attempted to summarize, with the help of a number of elements, how the study of variation can be addressed in the field of linguistic-translational research. The rectangular elements outlined in blue represent specific linguistic units chosen from among the paradigmatic possibilities of the source language (SL) in the ST. Any linguistic expression in the ST involves a sequence of elements that are verbalized after the author of the original text has reviewed the different possibilities offered by the system. On the basis of the different interference processes (cf. §2), the linguistic units of the ST are introduced into the target text or texts $\left(\mathrm{TT}_{1}, \mathrm{TT}_{2}\right.$, $\mathrm{TT}_{3} \ldots$ ) by means of diverse outputs or variants-the rectangles with green, orange, and red borders in Figure 2-chosen from among the paradigmatic possibilities existing in the target language $(T L)$ or languages $\left(T_{1}, T_{2}, T L_{3} \ldots\right)$ into which the ST is rendered.

traditions guiding the production of discourses in each one of those languages) (cf. also López Serena 2011).

${ }^{21}$ However much the examples provided here refer to languages that are, to a greater or lesser extent, related (i.e. they are all Indo-European languages).

Hikma 19 (1) (2020), $209-237$ 


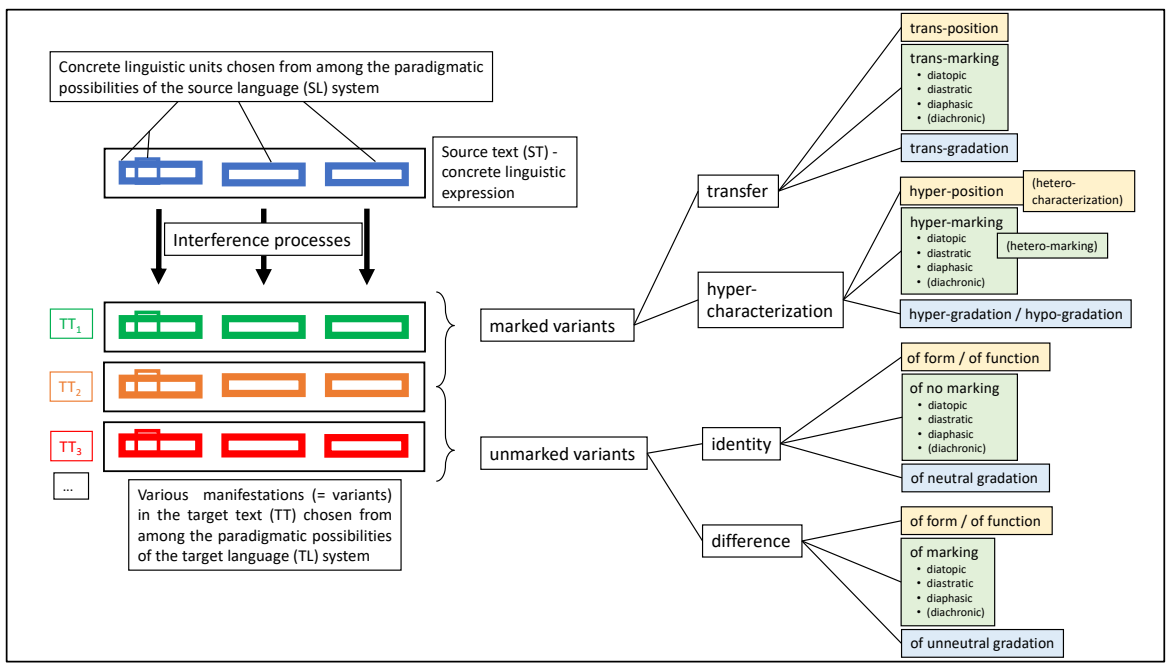

Figure 2. Interference phenomena and types of contact-based, diasystematic, and gradational variants in translated texts ${ }^{22}$

The different variants of the TT that reproduce content units of the ST can be marked or unmarked, according to the typology proposed here. As to the marked variants, I have drawn a distinction between the phenomena of transfer and hyper-characterization. Both explain the use of units or features that are positively present in the TT, and it is precisely because of this that they are manifestations of the "positive interference" that I have defined in the previous section. Transfer can be considered from the three perspectives of variation described above: contact-based, diasystematic, and gradational. With regard to the first of these ${ }^{23}$ within the phenomenon of transfer I call trans-position the appearance of a specific phenomenon in the TT which, calqued from the ST, produces an asystematic or abnormal-in the Coserian

22 In the figure, the categories represented in rectangles on a yellow background refer to phenomena inherent to contact-based variation, those in rectangles on a light green background to those inherent to diasystematic variation (except for the diachronic kind to which I will refer in n. 44) and those in rectangles with a clear blue background to gradational variation.

${ }^{23}$ In the typology proposed here, transfer is not totally identified with the concept of 'transferring' applied by Weinreich ([1953] 1967) to the field of language contact. For him, transferring phenomena, basically relating to the lexicon, contribute to increase the inventory of forms in the language or variety affected by interference, while modelling phenomena are those that involve some type of alteration in already existing forms, whether this be at a semantic or syntactic level (in the case of compound words and phraseological units). According to my proposal, transfer would encompass both types of interference.

Hikma 19 (1) (2020), 209 -237 
sense ${ }^{24}$-result in the TT, as can be seen in the example ${ }^{25}$ provided below in (1):

(1) The Italian (I) sentence credo che Laura abbia due sorelle [I think that Laura has (subjunctive) two sisters] translated into Spanish (S) as creo que Laura tenga dos hermanas [I think that Laura has (subjunctive) two sisters] can be explained as the result of a transposition in the TT affecting the use of the subjunctive in the subordinate clause. At a lexical level, trans-position would be, for example, the translation into Spanish of the English (E) sentence Peter left the keys on the table as Pedro dejó las llaves sobre la tabla, a common type of transfer in the case of the so-called "false friends" in the field of foreign language and L2 teaching (in this case, tabla [board] instead of mesa [table] in the Spanish TT).

In line with the second perspective of variation defined above, in the context of transfer I call trans-marking the transfer of a diasystematic mark ${ }^{26}$ from the ST to the TT. In translation, this transfer from the SL to the TL is not so difficult at a lexical level as it is at a syntactic one-above all in the case of unrelated historical languages_but naturally always poses a challenge even for the seasoned translator:

(2) An example of trans-marking is the expression palmarla (S) as the translation of the verb crepare (I) or the compound verb to snuff it $(\mathrm{E})$, since it incorporates a low diaphasic mark from the ST to the TT.

In accordance with the perspective of variation described in $\S 3$, in this case the transfer phenomenon is called trans-gradation, perceptible when a

\footnotetext{
${ }^{24}$ Cf. Coseriu ([1952] 1973); Del Rey (2020).

25 The examples given to illustrate the different types of variation that I propose here are not extracted from any corpus but based on intuition, a hermeneutic tool which is not only valid but also necessary in linguistic inquiry (cf. Itkonen 2003 [2008]: 47; López Serena 2019: 30-31). This paper entails a theoretical proposal aimed to be tested in empirical works on translated texts, but it is not my objective in this paper to empirically demonstrate the validity of my proposal. It has already partially been tested in previous works on the history of Romance languages where I have dealt with ancient translations from Latin (cf. Del Rey 2017, 2018a, 2018b, 2019).

${ }^{26}$ According to the conception of the variational space of any synchronically considered language, which I have put forward in Del Rey (2020), diasystematically marked variants can exist, as noted in $\$ 1$, in communicative immediacy (for example, the term palmarla (S) [to snuff it] in the sense of morir [die], i.e. [to reach the end of one's life], cf. RAE 2018, s. v. morir) and in communicative distance (expirar (S) [expire], in the same sense), alike. That is to say, marked variants, at either end of the continuum between conceptual orality and conceptual scripturality, oppose, according to my proposal, unmarked or standard variants (cf. Fig. 1) that can be employed at any point of the variational space of a language (returning to the example provided above in this note, it would be precisely the term morir (S) [die] which would lack diasystematic marking as an expression of the meaning that has been defined).
}

Hikma 19 (1) (2020), 209 -237 
superlative, intensified, or attenuated element in the ST is transferred to the TT:

(3) For instance, the adjective buenísimo (S) [very good] translated as ottimo (I) [very good] would be a good example of transgradation. At a discursive-syntactic level, the translation of the sentence It's John who did this job as Fue Juan quien hizo este trabajo (S) also represents a trans-gradational shift.

The other set of marked variants is formed by hyper-characterization phenomena, as I have called them. Here, it is also possible to distinguish variants in the TT in terms of the three perspectives of variation under consideration here. As regards contact-based variation, I use the term hyperposition to refer to those cases in which an asystematic or abnormal variantas before, in the Coserian sense-arises in the TT from the application of a mechanism of analogy, based on rules erroneously induced from limited use contexts, as occurs in the examples shown below in (4). This cognitive procedure is typical of hypercorrection phenomena (cf. Kabatek [1996] 2000), but I consciously avoid this term because it conveys prescriptive implications that do not agree with the descriptive nature of my typology:

(4) A sentence in the ST such as non credo che Laura abbia due sorelle (I) [I don't think that Laura has (subjunctive) two sisters] can produce the syntactically marked sentence no creo que Laura tiene dos hermanas (S) [I don't think that Laura has (indicative) two sisters], in accordance with the analogy, which ignores the context, credere che + subjuntive $(\mathrm{I})=$ creer que + indicative $(\mathrm{S})>$ non credere che + subjuntive $(\mathrm{I})={ }^{*}$ no creer que + indicative $(\mathrm{S})$. Similarly, the demonym estonio (S) can be translated into English due to hyper-position as Stonian, pursuant to the analogy: estar, estable, estilo $(\mathrm{S})=$ stay, stable, stile $(\mathrm{E})>{ }^{*}$ estonio $(\mathrm{S})=$ Stonian (E).

A fairly peculiar type of hyper-position, very infrequent in modern language translations, ${ }^{27}$ but not so in Latin ones, ${ }^{28}$ is hetero-characterization, which describes a marked variant in the TT, due to the influence of the SL on the TL, albeit not directly from the ST, in contexts in which there might have been a trans-position or direct calque from the original. The marked variant is explained by the contact influence of one language on another, which is not direct but indirect.

(5) For instance, the expression to contact somebody is frequently reproduced in Spanish as a trans-position-primarily in America, but

\footnotetext{
${ }^{27}$ Hence, in Figure 2, it is represented in brackets as an addendum to the hyper-position phenomenon.

${ }^{28}$ Cf. Del Rey (2018b).
}

Hikma 19 (1) (2020), 209 -237 
also increasingly more often in Spain-i.e. contactar a alguien, instead of the traditionally more normal variant-in the Coserian sense- contactar con alguien [to contact with somebody]. If the sentence I'll contact you soon were freely translated as te llamaré para atrás pronto (S) [l'll call you back soon] or te llamaré de vuelta pronto (S) [l'll call you back soon], this would give rise to an interference through hetero-characterization, owing to the fact that instead of the potential trans-position te contactaré pronto (S) [l'll contact you soon], another construction has been used, which in turn is explained by the influence (indirect, to wit, beyond this specific translation context) of the English language (SL) on the Spanish language (TL) - in America - in accordance with the pattern to call back > llamar para atrás/llamar de vuelta (S). ${ }^{29}$

The other type of hyper-characterization has to do with diasystematic variation. I am referring here to hyper-marking when an unmarked variant of the ST is translated as a diatopically, diastratically, or diaphasically marked variant in the TT. It is also possible to speak of hyper-marking in the fairly infrequent case that a marked unit in the domain of communicative immediacy becomes marked in the domain of communicative distance in the TT, or vice versa.

(6) For instance, the term crepare (I) [to snuff it], diaphasically marked as low, would correspond to a process of hyper-marking in the TT if the verb morir (S) [die], an unmarked or standard word in this language, or expirar (S) [expire], a marked term in the opposing variational domain, i.e. that of communicative distance, were to be found in the ST. At a syntactic level, a diatopically unmarked sentence, such as he asked her to marry him, can give rise to a diatopical hyper-marking in the Spanish TT la pidió que se casara con él, consisting in the use of the pronoun la as an indirect objecttypical of central-northern Iberian peninsula varieties-instead of the pronoun le-an unmarked or standard form.

It would also be conceivable to talk about hetero-marking if it were possible to confirm the translation of one type of diasystematic mark as another type. ${ }^{30}$

(7) For example, there would be hyper-marking if the phrase abuffarsi di dolci (I) [to stuff oneself with candy], geographically limited to the central-south of the Italian-speaking area, were

\footnotetext{
${ }^{29}$ Regarding this construction in American Spanish, cf. Otheguy (1993).

${ }^{30}$ Insofar as it is a less frequent type of hyper-characterization, in Figure 2 this phenomenon is represented in brackets as an addendum to the phenomenon of hyper-marking.
} 
translated as hincharse a/de pasteles (S), a diaphasically, but nondiatopically, marked expression. ${ }^{31}$

As to the third perspective of variation defined here, what I call hypergradation is a type of hyper-characterization involving the use of a linguistic unit of the TT representing a (greater) degree of intensification with respect to the original structure, and hypo-gradation, the opposite phenomenon, viz. a kind of hyper-characterization consisting in the use of a linguistic unit of the TT representing a (greater) degree of attenuation with respect to the ST:

(8) For example, if bueno (S) [good] were translated as ottimo (I) [very good], this would be a case of hyper-gradation. At a discursivesyntactic level, if John is silly were translated as Juan es probablemente tonto (S) [John is probably silly], in which an attenuating modal particle has been introduced, modifying the illocutionary strength and, therefore, the degree of commitment of the original statement, this would be a case of hypo-gradation.

Before commenting on the phenomena involving unmarked variants, I would first like to make three important observations. The first has to do with the conscious or unconscious character of these positive interference phenomena (cf. Jakobsen 2017). Trans-position can be the result of a conscious translation practice, above all when the translator considers that the $\mathrm{SL}$ is more prestigious or culturally prevalent than the $\mathrm{TL},{ }^{32}$ although also unconscious, which by and large leads to the traditionally considered-from a prescriptive perspective-'translation errors', frequent in texts produced by translators who do not have a perfect command of the TL. Hyper-position, however, is always unconscious, ${ }^{33}$ for, as already noted, it is based on an erroneous analogy which, as a rule, also gives rise to such translation errors. As regards diasystematically marked variants, trans-marking is necessarily conscious, except perhaps when marked units coincide formally in related

\footnotetext{
${ }^{31}$ At any rate, according to the chain of varieties model (cf. Koch and Oesterreicher [1990] 2007: 37-40; Del Rey 2020), insofar as diatopic variants can function as diastratic ones and the latter as diaphasic ones, distinguishing between them at each one of these levels is not, in the main, a simple task.

32 Which is a matter of course in the processes of elaboration (cf. Kloss [1952] 1978) that allow languages with a scant or non-existent literary tradition access to communicative distance, as has been demonstrated in the case of primitive Romance languages (cf. Raible 1996; Frank-Job and Selig 2016; Del Rey 2016b). Toury $(1995,315)$ also points in this direction: "On occasion, this would even make it possible to deliberately adopt interference as a strategy, e.g., in an attempt to enrich the target culture/language, in domains regarded as needing such enrichment, in an act of cultural planning."

33 Hetero-characterization, however, is a mostly conscious phenomenon of hypercharacterization.
} 
languages ${ }^{34}$ Hyper-marking is, generally speaking, a conscious translation process, ${ }^{35}$ guided by some or other specific purpose intentionally sought by the translator in the TT, except perhaps when it is concomitant with a transposition (cf. infra Example 10). Concerning gradational variation, transgradation normally involves an unconscious translation process, but the semantic, morphosyntactic, or discursive-syntactic modification implied by hyper-gradation requires the translator to take a conscious stance.

In relation to the foregoing, the second observation involves the conceptual profile ${ }^{36}$ of translations in which the contact-based variation phenomena that I have called trans-position and hyper-position usually occur. While the phenomenon of trans-position is possible, although not that frequent, even in translations relating to communicative distance (technical, literary, administrative, etc.), as before, especially when the language of the ST is socially held in high esteem by a linguistic community into which it is translated, the phenomenon of hyper-position only appears in translation contexts pertaining to communicative immediacy (social networks, poorly elaborated comments in chats or on blogs and websites, etc.) and eventually also in automatic translations. Translation, inasmuch as it involves a process of written fixation, allows translators to ponder on the texts that they produceat least when the lack of time does not lead to instantaneously produced texts. The mere fact of departing from a ST requires metalinguistic attention. The processes of hyper-position are more typical of contexts of interference in which such reflection does not occur, i.e. in spontaneous discourses, although not necessarily inherent to communicative immediacy. In a discussion after a conference, speakers can produce hyper-position solutions if they do not have

\footnotetext{
${ }^{34}$ Thus, a French word diaphasically marked as high, like relevant [relevant], can be translated into Spanish as relevante, also a term diaphasically marked as high, without the translator reflecting on the diasystematic status of this adjective.

${ }_{35}$ Unlike hetero-marking, which can often occur unconsciously, in the sense that a translator who is perfectly familiar with both the SL and the TL can perceive a diasystematically marked variant in the ST, but be unfamiliar with the domain of variation affected by the said variant and, therefore, can choose a variant in the TL that is marked but not at the same level of variation as the variant in the ST-for instance, a diatopically marked variant in the TT can be chosen as the translation of a variant diaphasically marked as low in the ST. Conscious hetero-marking would be, of course, the substitution of a variant marked in the ST, in the domain of communicative immediacy, by a variant marked in the TT, in the domain of communicative distance-or vice versa-which would seem rather odd.

${ }^{36}$ By "conceptual profile", I am referring to the linguistic characteristics that determine as a whole the place occupied by a particular text on the continuum between communicative immediacy and communicative distance, in terms of the communicative conditions determined by the extralinguistic aspects of communication (cf. Koch and Oesterreicher [1990] 2007: 26-27).
}

Hikma 19 (1) (2020), $209-237$ 
a full command of the language being used, notwithstanding the fact that this situation is prototypical of communicative distance. ${ }^{37}$

And, lastly, a third observation vis-à-vis the set of phenomena that give rise to marked variants in the TT: it should be stressed that contact-based, diasystematic, and gradational marking can coexist in some solutions, without there necessarily having to be incompatibilities between the different types defined above (cf. §2). This is what happens with the phenomena of transposition and trans-marking, which are not exclusive, but, quite to the contrary, often occur simultaneously.

(9) For example, the translation of the word decedere (I) [to pass away], which belongs to a high register, as deceder (S) would be both a trans-position and a trans-marking, since for it to occur effectively, it could only function as a term diaphasically marked as high. ${ }^{38}$

Trans-position and hyper-marking can also occur together, this phenomenon being an unintended and, therefore, unconscious result of the first one, most probably also unconscious.

(10) For instance, an unmarked variant in Italian such as letto [bed] can produce, through its trans-position into Spanish, the term lecho which is diaphasically marked as high in this language and, therefore, hyper-marked with respect to the original text.

Finally, gradational marking can occur in conjunction with the processes of trans-position, trans-marking, hyper-position, and hyper-marking.

With respect to unmarked variants, I distinguish between the phenomena of identity and difference. In line with the idea that I have assumed as regards linguistic interference (§2), even when unmarked variants are identified in the TT, it is indeed possible to talk about interference (of the negative kind when it comes to identity and difference). Identity is produced when a particular unit of the ST, which is not diasystematically marked in the $\mathrm{SL}$, is translated as an equivalent formal and/or functional unit in the TT, also diasystematically unmarked (cf. Del Rey 2018a: 57-59). ${ }^{39}$ So, from this definition it can be deduced that the identity of form and/or function and that relating to the absence of diasystematic marking-i.e. to its standard

${ }^{37}$ We could even place the types of translated texts on a continuum according to their degree of elaboration and, therefore, to the greater or lesser likelihood of discovering some type of hyperposition in them.

${ }^{38}$ The combination of trans-position and trans-marking is also the most frequent in the use of Latinisms, as is the case in the stages of linguistic elaboration referred to in $n .32$.

${ }^{39}$ It should be noted that we can speak of interference in this case because translators at least have the virtual opportunity to choose other paradigmatic possibilities that differ (more) from the ST. 
character in both the SL and the TL, cf. Fig. 1-coexist in translation variants that are understood as having resulted from this phenomenon. Likewise, as to gradational variation, the phenomenon of identity is evidenced by a nonhyper-gradated or hypo-gradated use, that is, neutral, of the linguistic unit or structure being translated.

(11) For instance, the translation of morire (I) [to die] as morir (S) would represent a solution of identity. At a syntactic level, the translation of the French sentence Si tu as faim, mange (F) [if you are hungry, eat] as se hai fame, mangia (I) also represents a solution of identity.

In relation to the phenomenon which I have called difference, the three perspectives of variation described in this section should also be characterized. With regard to contact-based variation, difference refers to the selection of a normal or standard variant in the TT that corresponds to another normal or standard one in the ST, but with which it does not coincide formally and/or functionally. ${ }^{40}$

(12) For example, the phrase la porta non è chiusa (I) [the door is not closed] translated as la puerta está abierta (S) [the door is open] evidences a solution deriving from difference. The effects of difference are harder to perceive in the lexicon, although it is relatively common in the use of parasynonymy for translating certain words: for instance, the adjective afectuoso (S) [affectionate] translated as tendre $(\mathrm{F})$ [tender] evidences a process of difference of form, since the variant affectueux exists in French.

With respect to diasystematic variants, the solution of difference is apparent in the selection of diatopically, diastratically, and diaphasically unmarked variants in the TT when marking does indeed exist in the ST.

(13) For instance, the translation of crepare (I) [to snuff it] as morir (S) [die] reflects this process of difference. At a syntactic level, the phenomenon that I call difference of marking always implies that of difference of form and/or function. For example, the translation of the sentence essendosi verificato l'errore, sono state effettuate due prove (I) [the error having been verified, two tests were performed], which evidences the use of syntactic structures diastratically and diaphasically marked as high, as cuando se verificó el error, se hicieron dos pruebas (S) [when the error was verified, two tests were performed], where the syntactic structures are perfectly standard in the $\mathrm{TL}$, is also evidence of the phenomenon referred to here as

\footnotetext{
${ }^{40}$ Here, it should be observed that, in contrast to the arguments set out in the previous note, we can speak of interference in this case because the translator has at least the virtual opportunity to choose other paradigmatic possibilities that are (more) similar or identical to the variant in the ST.
}

Hikma 19 (1) (2020), 209 -237 
difference of marking with respect to the selection of syntactic relations in the translation.

In the case of gradational variation, the difference would consist in the conversion of an intensified or attenuated unit or structure of the ST into a neutral unit or structure in the TT.

(14) For example, the translation of ottimo (I) [very good] as bueno (S) [good] corresponds to a difference of gradation. At a discursivesyntactic level, the translation of the sentence John is a bit odd as Juan es raro (S) [John is odd] also involves a difference of gradation, insofar as the attenuation strategy disappears in the TT, thus giving rise to a more aseptic sentence.

From the explanation relating to Example (11) it can be deduced that the difference of form and/or function and the difference of marking are totally compatible, even when this involves variants inherent to communicative immediacy:

(15) For instance, the translation of quiero vivir (S) [I want to live] as non voglio crepare (I) [I don't want to snuff it] combines the absence of formal correspondence and that of diasystematic marking in the MT.

Besides, the difference of gradation is also compatible with others types of difference.

And, as has been seen in relation to the phenomena involving marked variants, nor are those of identity and difference, which produce unmarked elements in translations, incompatible.

(16) Indeed, the translation of lecho (S) [bed] as letto (I) not only corresponds to a process of identity (and not of trans-position as we have seen, since in the TL letto is an unmarked word), but also to a difference of marking (as the diaphasically high mark of the noun in the ST disappears in the Italian translation).

The phenomena of trans-marking, hyper-marking, heterocharacterization, hetero-marking, hyper-gradation, and hypo-gradation ${ }^{41}$ can

41 These last two phenomena, i.e. those involving positive interference due to gradational variation, require a comparative context to be noticeable. Furthermore, gradational variation can affect very different relationships between language variants, depending on the more or less allencompassing character that we want to give the concept of gradation. This means that, unlike what occurs in other types of phenomena, on many occasions gradationally marked variants are only considered as such by comparing them with the ST (cf. §3). For example, if we found in the TT the word rey (S) [king] as a translation of prince (E) in the ST, we might be forgiven for thinking that it is a hyper-gradation, provided that we accept that hierarchical scales can also be regarded as a manifestation of semantic gradation.

Hikma 19 (1) (2020), 209 -237 
only be determined if the ST is available, as is also the case with the phenomena of negative interference, for which translation provides an ideal context of analysis, unlike what occurs in prototypical oral situations of language contact, where negative interference is very hard to recognize. Those of trans-position and hyper-position represent a type of marking that is evident as a fact of contact even outside the specific field of translation, namely, such phenomena are identifiable within highly specific spatiotemporal occurrences (for instance, in brief sentences as a fortuitous product of a particular speaker). Of course, it is necessary-or at the very least convenient-that the analyst knows which languages are involved in the contact to explain different manifestations of interference.

There are another two concepts that are essential for understanding the scope of this classification and the interrelation between the diverse types of phenomena: convergence and divergence (cf. Del Rey 2018a: 57-59). Indeed, from a comparative perspective that is of interest in translation studies, what the phenomena of transfer (which produces marked variants in the TT by means of positive interference) and identity (which gives rises to unmarked ones due to negative interference) have in common is the fact that they coincide with the ST, hence both processes represent convergence phenomena. For their part, both hyper-characterization (the product of positive interference) and difference (the result of negative interference) are divergence phenomena, for in both cases the variants resulting from the process of interference in the TT differ from those present in the ST (cf. Fig. 3 ). Thus, the quantity of marked and unmarked phenomena according to the classification proposed here determines the convergent or divergent tendency of the TT with respect to the ST 


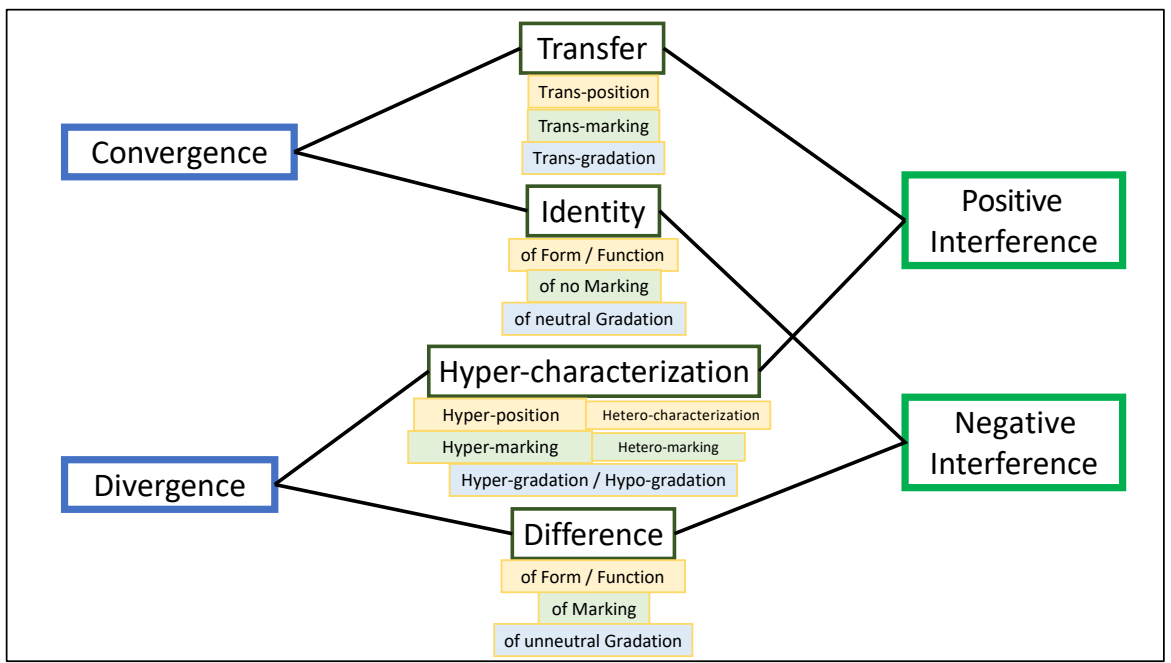

Figure 3. Positive interference, negative interference, convergence, and divergence in translated texts

As noted in §2, the applicability of this classification needs to be tested in specific and exhaustive analyses of texts translated from and into different languages. Nonetheless, I am of the mind that this proposal for interference categories, from the triple perspective of contact-based, gradational, and diasystematic variation, is an important step forward in research on language contact and its reflection in written texts ${ }^{42}$. In the last section, I will refer briefly to the fields of linguistic and discourse research for which the typology put forward here may be interesting.

\section{THE VIABILITY OF APPLYING THIS TAXONOMIC PROPOSAL}

The classification presented in $\S 3$ is pretended to be, as already noted, supra-idiomatic, and I believe that it can yield satisfactory results in interdisciplinary studies involving translatology and linguistics. In both synchronic and diachronic linguistics, corpus linguistics has known how to

\footnotetext{
${ }^{42}$ Besides, it must be stressed that with this classification my aim was to describe different types of translational phenomena, not to explain the reasons underlying the preferential use of convergence or divergence phenomena in translations, what is also very relevant for translation theory (cf. Even-Zohar [1981] 1990, 77).
}

Hikma 19 (1) (2020), 209 -237 
exploit the viability of corpora of translations, especially in the case of parallel corpora. ${ }^{43}$ The classification proposed in $\S 3$ may be particularly useful in the analysis of these corpora, since the comparison between the ST and several translations allows us to establish the way in which transfer, hypercharacterization, identity, and difference-i.e. convergence and divergencefunction in the production of target discourse. Sure enough, parallel corpora provide a perfect comparable context of variation, in the sense that the relationships between the linguistic elements of translations represent the effective expression of a relatively broad paradigm of variation.

In the case of corpora of translations of the same ST, but without this being present, although the available texts also provide an ideal context for studying diasystematic variation, it is not now possible to analyse contactbased variation easily. Indeed, a series of translations of the same unavailable ST enables us to differentiate between more or less marked variants in the context of communicative immediacy and communicative distance according to the levels of diatopical, diastratic, and diaphasic variation, as occurs in the case of parallel corpora, given the high level of comparability that they allow for. This is also the case with gradational variation. Similarly, both parallel corpora and those of translations without the ST in view allow for the study of diachronic variation, inasmuch as it is possible to define a sufficiently broad time frame based on the different dating of the versions. ${ }^{44}$ However, nor can the phenomena of negative interference (identity and difference in my classification), which in themselves are difficult to verify in prototypical language contact situations, be easily identified in corpora of translations of the same ST, if this is not available. But when this and at least one TT-or several TTs, as is the case in parallel corpora-are available, the study of integral contact-based variation-which includes the phenomena of transposition, hyper-position, hetero-characterization, identity, and difference of form and/or function-is indeed possible. In short, it is thanks to the comparison between the ST and the TT(s) that we can perform a comprehensive analysis on the convergence and divergence phenomena guiding the translation process.

Parallel corpora can comprise texts with a very different conceptual profile (cf. n. 36). As to historical linguistics, the diverse translations of a Latin

\footnotetext{
${ }^{43}$ A parallel corpus consists in the original text or texts - in the SL or language A-and its versions translated into Language B (cf. Baker 1995; Del Rey 2016a).

${ }^{44}$ Coseriu does not include diachronic variation in his modelling of the diasystem. However, in the context of translation studies it is indeed possible to talk about diachronically marked variants susceptible to being involved in the phenomena that I have called here trans-marking, hypermarking, hetero-marking, and difference of marking. For instance, the deliberate use of archaisms in Don Quijote, such as fermosa [beautiful], can be interpreted as a diachronic mark which can be translated into Italian using the adjective formosa in a procedure of trans-marking.
} 
text performed at different times into the language(s) under study are very useful. A corpus of this type offers researchers the "chimerical" opportunity to discover how the same was said in the same language in different periods, hence its enormous interest for the study of diachronic variation (cf. Castillo 2005: 232-233).

But corpora of translations cannot and should not only include texts that we associate with the field of conceptual scripturality, but also those in which translation does not imply a meditated or planned act of reflection, as is the case with hasty translations of tourist information for hotels, the spontaneous translation of ad hoc instructions for foreigners, the translation of texts with a large media impact on social networking sites, etc. In these types of texts, the categories of analysis proposed in $\S 4$ can be very helpful for explaining the interference phenomena taking place between the ST and the TT, thus fully explaining language variation in translated texts.

The typology proposed here can also provide an effective discoverybased methodology in the field of foreign language and L2 teaching. ${ }^{45}$ Undeniably, translation exercises are still a productive tool for learning foreign languages. The level of competence of students in its use will determine the types of interference reflected in their translations: for instance, as regards contact-based variation, a greater number of trans-positions and hyperpositions at the initial levels, as well as a greater reflective capacity as to negative interference at higher levels. Also regarding diasystematic variation, those students more competent ${ }^{46}$ in the use of the TL will be able to discern which of the paradigmatic possibilities offered by the TL reflect a process of trans-marking, hyper-marking, hetero-marking, or difference of marking.

Naturally, despite the supra-idiomatic vocation of this typology, the particularities of each language in translation contexts can recommend the qualification or even the modification of the categories proposed here. For the time being, suffice it to present this classification, aimed at explaining variation phenomena in translated texts according to the clarifications and caveats provided above, to the academic community. It is my hope that this proposal will contribute to make further inroads into interdisciplinary research between translatology, corpus linguistics, applied linguistics, and variational linguistics,

\footnotetext{
45 Interference processes in this field was already explored by Toury (1982).

${ }^{46}$ According to Kabatek (2005, 160), "el saber que nos indica la selección de los elementos gramaticales y variacionales y las TD [tradiciones discursivas] adecuadas es lo que puede llamarse nuestra competencia comunicativa" [the knowledge that shows us the selection of grammatical and variational elements and the adequate DTs (discourse traditions) is what could be called our communicative competence]. In this respect, Toury $(1982,62)$ states that "[a]ny translation [...] represents its producer's competence in 'communication in translated utterances', but cannot be taken as a direct evidence of his overall competence in the target language".
} 
despite the fact that there is still much work to be done to integrate perspectives, models, and research interests.

\section{REFERENCIAS BIBLIOGRÁFICAS}

Albelda Marco, M. (2005). La intensificación en el español coloquial. PhD dissertation. University of València, Spain.

Albrecht, J. (2017). Sprachkontakt - schriftlicher Sprachkontakt Übersetzung (lato sensu) - und Übersetzung (stricto sensu) als Fakten der Sprachgeschichte und als Gegenstand der Sprachgeschichtsschreibung. In S. Dessì Schmid and H. Aschenberg. (Eds.), Romanische Sprachgeschichte und Übersetzung (pp. 41-52). Heidelberg, Germany: Winter.

Baker, M. (1995). Corpora in Translation Studies: An Overview and Some Suggestions for Future Research. Target, 7(2), 223-243.

Bolinger, D. (1972). Degree words. Den Haag, Holland: Mouton.

Brumme, J., and Espunya, A. (2011). Background and justification: research into fictional orality and its translation. In J. Brumme and A. Espunya. (Eds.), The translation of fictive dialogue (pp. 7-31). Amsterdam, Holland: Rodopi.

Coseriu, E. ([1952] 1973). Sistema, norma y habla. In Teoría del lenguaje y lingüística general (pp. 11-113). 3rd ed. Madrid, Spain: Gredos.

Coseriu, E. ([1957] 1988). Sincronía, diacronía e historia. El problema del cambio lingüístico. 3rd ed. Madrid, Spain: Gredos.

Coseriu, E. (1977). Sprachliche Interferenz bei Hochgebildeten. In H. Kolb and H. Lauffer. (Eds.). Sprachliche Interferenz: Festschrift für Werner Betz (pp. 77-100). Tübingen, Germany: Niemeyer.

Coseriu, E. (1980). "Historische Sprache" und "Dialekt". In J. Göschel et al. (Eds.), Dialekt und Dialektologie. Ergebnisse des internationalen Symposions 'Zur Theorie des Dialekts'. Marburg/Lahn, 5.-10. September 1977 (pp. 106-122). Wiesbaden, Germany: Steiner.

Del Rey Quesada, S. (2016a). Traducción y tradición en los corpus: nuevas perspectivas para la lingüística histórica. In J. Kabatek. (Ed.), Lingüística de corpus y lingüística histórica iberorrománica (pp. 40-56). Berlin/Boston, Germany/England: De Gruyter. 
Del Rey Quesada, S. (2016b). Interferencia latín-romance en Alfonso X: la traducción como pretexto de la elaboración sintáctica. La corónica, 44(2), 75-109.

Del Rey Quesada, S. (2017). (Anti-)Latinate Syntax in Renaissance Dialogue: Romance Translations of Erasmus's Uxor Mempsigamos. Zeitschrift für romanische Philologie, 133(3), 673-708.

Del Rey Quesada, S. (2018a). El De senectute de Cicerón en romance (ss. XIV-XVI): un estudio sintáctico contrastivo. Anuari de Filologia. Estudis de Lingüística, 8, 21-56.

Del Rey Quesada, S. (2018b). Latinismo, antilatinismo, hiperlatinismo y heterolatinismo: la sintaxis de la prosa traducida erasmiana del Siglo de Oro. In M. L. Arnal Purroy et al. (Eds.), Actas del X Congreso Internacional de Historia de la Lengua Española (pp. 623-645). Zaragoza, Spain: Institución Fernando el Católico.

Del Rey Quesada, S. (2019). Participial and Gerundial Clauses in 16th Century Spanish Prose: Latinate Syntax between Convergence and Divergence in Translation. Belgian Journal of Linguistics, within the monographic issue coordinated by B. Cornillie and B. Drinka, Latin influence on the syntax of the languages of Europe, 33, 43-80.

Del Rey Quesada, S. (2020). Lo marcado y lo no marcado en la cadena de variedades: apuntes para una nueva propuesta. In K. Grübl et al. (Eds.), Was bleibt von kommunikativer Nähe und Distanz? Tübingen,Germany: Narr. (In press)

Del Rey Quesada, S., del Barrio de la Rosa, F. and González Gómez, J. (2018). Introducción: lenguas en contacto, traducción y variación desde una perspectiva filológica. In S. Del Rey Quesada et al. (Eds.), Lenguas en contacto, ayer y hoy. Traducción y variación desde una perspectiva filológica (pp. 9-24). Frankfurt a. M. et al., Germany et al.: Peter Lang.

Flydal, L. (1951). Remarques sur certains rapports entre le style et l'état de langue. Norsk tidsskrift for sprogvidenskap, 16, 241-258.

Frank-Job, B., and Selig, M. (2016). Early evidence and sources. In A. Ledgeway and M. Maiden. (Eds.), The Oxford Guide to the Romance Languages (pp. 24-34). Oxford, England: Oxford University Press.

Göpferig, S. (2017). Cognitive Functions of Translation in L2 Writing. In J. W. Schwieter and A. Ferreira. (Eds.), The Handbook of Translation and Cognition (pp. 402-422). Malden, MA, USA: Blackwell. 
Haßler, G. (2001). Übersetzung als Sprachkontakt, In G. Haßler. (Ed.), Sprachkontakt und Sprachvergleich (pp. 153-171). Münster, Germany: Nodus.

Hickey, R. (Ed.). (2013). The Handbook of Language Contact. Oxford, England: Blackwell.

House, J. (2009). Translation. Oxford, England: Oxford University Press.

Itkonen, E. ([2003] 2008). ¿Qué es el lenguaje? Introducción a la Filosofía de la Lingüística. Introduction, Spanish version and Notes by A. López Serena. Madrid, Spain: Biblioteca Nueva.

Jääskeläinen, R., and Tirkkonen-Condit, S. (1991). Automatised Processes in Professional vs. Non-Professional Translation: A Think-Aloud Protocol Study. In S. Tirkkonen-Condit. (Ed.), Empirical Research in Translation and Intercultural Studies: Selected Papers of the TRANSIF Seminar, Savonlinna 1988 (pp. 89-110). Tübingen, Germany: Narr.

Jakobsen, A. L. (2017). Translation Process Research. In J. W. Schwieter and A. Ferreira. (Eds.), The Handbook of Translation and Cognition (pp. 2149). Hoboken/Malden, USA: Willey-Blackwell.

Kabatek, J. (1997). Zur Typologie sprachlicher Interferenzen. In W. W. Moelleken and P. J. Weber. (Eds.), Neue Forschungsarbeiten zur Kontaktlinguistik (pp. 232-241). Bonn, Germany: Dümmler.

Kabatek, J. ([1996] 2000). Os falantes como lingüistas. Tradición, innovación e interferencias no galego actual. Vigo, Spain: Xerais.

Kabatek, J. (2005). Tradiciones discursivas y cambio lingüístico, Lexis, 29(2), 151-177.

Kloss, H. ([1952] 1978). Die Entwicklung neuer germanischer Kultursprachen seit 1800. 2nd ed. Düsseldorf, Germany: Schwann (Sprache der Gegenwart, 37).

Koch, P. (1997). Diskurstraditionen: zu ihrem sprachtheoretischen Status und ihrer Dynamik. In B. Frank et al. (Eds.), Gattungen mittelalterlicher Schriftlichkeit (pp. 43-79). Tübingen, Germany: Narr (ScriptOralia, 99).

Koch, P., and Oesterreicher, W. (2007). Lengua hablada en la Romania: español, francés e italiano. Spanish version by A. López Serena. Madrid, Spain: Gredos.

Kupsch-Losereit, S. (2004). Interferenz in der Übersetzung. In H. Kittel and P. Frank. (Eds.), Übersetzung - Translation - Traduction (vol. 1, pp. 543549). Berlin et al., Germany et al.: De Gruyter. 
López Serena, A. (2007). La importancia de la cadena variacional en la superación de la concepción de la modalidad coloquial como registro heterogéneo. Revista Española de Lingüística, 37, 371-398.

López Serena, A. (2011). La doble determinación del nivel histórico en el saber expresivo. Hacia una nueva delimitación del concepto de 'tradición discursiva'. Romanistisches Jahrbuch, 62, 59-97.

López Serena, A. (2019). La lingüística como ciencia humana. Una incursión desde la filosofía de la ciencia. Madrid, Spain: Arco/Libros.

Lyons, J. (1977). Semantics. Cambridge, England: Cambridge University Press.

Malamatidou, S. (2016). Understanding Translation as a Site of Language Contact: The Potential of the Code-Copying Framework as a Descriptive Mechanism in Translation Studies. Target, 28, 399-423.

Martín de León, C. (2017). Mental Representations. In J. W. Schwieter and A. Ferreira. (Eds.), The Handbook of Translation and Cognition (pp. 402422). Malden, MA, USA: Blackwell.

Mattheier, K. J. (1996). Varietätenkonvergenz: Überlegungen zu einem Baustein einer Theorie der Sprachvariation. Sociolinguistica, 10, 31-52.

Newmark, P. (1991). The Virtues of Interference and the Vices of Translationese. In About Translation (pp. 78-86). Clevedon, England: Multilingual Matters.

Otheguy, R. (1993). A reconsideration of the notion of loan translation in the analysis of U.S. Spanish. In A. Roca and J. M. Lipski. (Eds.), Spanish in the United States (pp. 21-46). Berlin/Boston, Germany/England: De Gruyter.

RAE (Real Academia Española). (2018). Diccionario de la lengua española. From https://dle.rae.es/

Raible, W. (1996). Relatinisierungstendenzen. In G. Holtus et al. (Eds.), Lexikon der Romanistischen Linguistik (LRL) Band II/1: Latein und Romanisch. Historisch-vergleichende Grammatik der romanischen Sprachen (pp. 120-134). Tübingen, Germany: Niemeyer.

Selig, M. (2011). Konzeptionelle und/oder diaphasische Variation? In S. Dessì-Schmid et al. (eds.), Rahmen des Sprechens: Beiträge zu Valenztheorie, Varietätenlinguistik, Kreolistik, Kognitiver und Historischer Semantik. Peter Koch zum 60. Geburtstag (pp. 111-126). Tübingen, Germany: Narr. 
Toury, G. (1982). The Communication Situation and the Production of Interference Forms by L2 Learners. RELC Journal, 13(2), 62-77.

Toury, G. (1995). Descriptive Translations Studies and Beyond. Amsterdam, Holland: John Benjamins.

Weinreich, U. ([1953] 1967). Languages in contact. Findings and problems. London/Den Haag/Paris, England/Holland/France: Mouton \& Co. 